\title{
Netazepide, a gastrin/ $\mathrm{CCK}_{2}$ \\ Correspondence
} receptor antagonist, causes dose-dependent, persistent inhibition of the responses to pentagastrin in healthy subjects

Malcolm Boyce, ${ }^{1}$ Steve Warrington ${ }^{1} \&$ James Black ${ }^{2}$

Dr Malcolm Boyce, Hammersmith

Medicines Research, Cumberland Avenue, London NW10 7EW, UK.

Tel.: +44 2089614130

Fax:+44208961 8665

E-mail:mboyce@hmrlondon.com

\section{Keywords}

gastrin receptor antagonist, netazepide, pentagastrin, YF476

Received

3 October 2012

Accepted

11 February 2013

Accepted Article

Published Online

21 February 2013

${ }^{1}$ Hammersmith Medicines Research, Central Middlesex Hospital, London NW10 7NS, UK and ${ }^{2} J a m e s$ Black Foundation, Half Moon Lane, Dulwich, London SE24 9JE, UK

\section{WHAT IS ALREADY KNOWN ABOUT THIS SUBJECT}

- Gastrin controls secretion of gastric acid and growth of mucosal cells, especially enterocromaffin-like and parietal cells.

- Hypergastrinaemia can be harmful, and there is an unmet clinical need for a gastrin receptor antagonist.

- Nonclinical studies have shown that netazepide is a potent, highly selective and orally active gastrin/ $\mathrm{CCK}_{2}$ receptor antagonist.

- In healthy subjects, single oral doses of netazepide caused sustained dose-dependent increases in $24 \mathrm{~h}$ gastric $\mathrm{pH}$, but that effect was mostly lost after repeated dosing, whereas the effect of omeprazole on $24 \mathrm{~h}$ gastric $\mathrm{pH}$ persisted. However, like omeprazole, netazepide increased $24 \mathrm{~h}$ circulating gastrin, consistent with persistent suppression of gastric acid secretion.

\section{WHAT THIS STUDY ADDS}

- Despite tolerance to its effect on $\mathrm{pH}$, during repeated dosing netazepide causes persistent inhibition of pentagastrin-induced $\mathrm{H}^{+}$secretion. - Netazepide is a potential new treatment for acid-related conditions and the trophic effects of hypergastrinaemia.

\section{AIMS}

To confirm by means of pentagastrin, a synthetic gastrin agonist, that netazepide is a gastrin/ $\mathrm{CCK}_{2}$ receptor antagonist in healthy subjects, and that antagonism persists during repeated dosing.

\section{METHODS}

We did two studies in which we infused pentagastrin $\left(0.6 \mu \mathrm{g} \mathrm{kg}^{-1} \mathrm{~h}^{-1}\right.$ intravenously), aspirated gastric secretion and measured the volume, $\mathrm{pH}$ and $\mathrm{H}^{+}$secretion rate of the gastric aspirate. First, we did a double-blind, five-way crossover study $(n=10)$ to assess the effect of single oral doses of netazepide $(1,5,25$ and $100 \mathrm{mg})$ and placebo on the response to pentagastrin. Then, we did a single-blind, placebocontrolled study $(n=8)$ to assess the effect of the first and last oral doses of netazepide $(100 \mathrm{mg})$ twice daily for 13 doses on the response to pentagastrin.

\section{RESULTS}

Netazepide was well tolerated. After placebo, pentagastrin increased the volume and $\mathrm{H}^{+}$secretion rate and reduced the $\mathrm{pH}$ of gastric aspirate. Compared with placebo, single doses of netazepide caused dose-dependent inhibition of the pentagastrin response $(P<0.02)$; netazepide $(100 \mathrm{mg})$ abolished the response. After 13 doses, the reduction in volume and $\mathrm{H}^{+}$secretion rate persisted $(P<0.001)$, but the $\mathrm{pH}$ effect was mostly lost.

\section{CONCLUSIONS}

Netazepide is an orally active, potent, competitive antagonist of human gastrin/CCK 2 receptors. Antagonism is dose dependent and persists during repeated dosing, despite tolerance to the effect on $\mathrm{pH}$. Further studies are required to explain that tolerance. Netazepide is a tool to study the physiology and pharmacology of gastrin, and merits studies in patients to assess its potential to treat gastric acid-related conditions and the trophic effects of hypergastrinaemia. 


\section{Introduction}

Nonclinical studies have shown that netazepide (YF476) is a potent, selective, competitive and orally active antagonist [1-3] of $\mathrm{CCK}_{2} /$ gastrin receptors [4]. We have shown in healthy subjects that single oral doses of netazepide cause dose-dependent, sustained increases in basal and foodstimulated $24 \mathrm{~h}$ gastric $\mathrm{pH}$, consistent with suppression of gastric acid production via antagonism of gastrin receptors [5]. We have also shown that repeated doses of netazepide lead to tolerance to that effect on gastric $\mathrm{pH}$; however, repeated doses increased plasma gastrin, suggesting persistent suppression of gastric acid secretion [6]. Subsequent studies in rodents have also shown that netazepide increases circulating gastrin, via gastric acid suppression and upregulation of the gastrin gene [7-16].

Here we report two more studies in healthy subjects, a single-dose study and a repeated-dose study. The objectives were to confirm that netazepide causes dosedependent antagonism of gastrin receptors and that antagonism persists during repeated dosing. We used intravenous pentagastrin - a synthetic pentapeptide consisting of $\beta$-alanine and the C-terminal tetrapeptide of gastrin - as an agonist to stimulate gastrin receptors [17].

We presented the results of the second study at a meeting of the Clinical Section of the British Pharmacological Society [18].

\section{Methods}

We carried out the studies at our facilities in the Central Middlesex Hospital, London, UK, in accordance with the ICH Guideline for Good Clinical Practice and the Declaration of Helsinki. Brent Ethics Committee approved the studies. Subjects gave written informed consent. The studies are registered at ClinicalTrials.gov as NCT01601418 and NCT01601405.

\section{Materials}

Ferring A/S (Vanløse, Denmark) supplied capsules of netazepide $(1,5,25$ and $100 \mathrm{mg})$ and matching placebo. The hospital pharmacy packed and labelled treatments, and randomized subjects to treatment in the single-dose study using sequentially numbered containers. Pentagastrin was supplied by Cambridge Laboratories Ltd (Wallsend, Tyne and Wear, UK) as ampoules of $500 \mu \mathrm{g}(2 \mathrm{ml})^{-1}$.

\section{Study design}

Single-dose study The study was double-blind, randomized, single-dose and five-way complete crossover in design. There was 1 week between successive treatments. The protocol required 10 healthy nonsmoking men or women not at risk of pregnancy to complete the study. The other entry criteria included the following: Helicobacter pylori negative (by ${ }^{13} \mathrm{C}$-urea breath test); negative urinary screen for drugs of abuse; negative antibody tests for HIV 1 and 2 and hepatitis $B$ and $C$ viruses; and no medication for the previous 14 days. Subjects fasted from midnight, then at about $08.00 \mathrm{~h}$ we passed a nasogastric tube ( 14 gauge Salem sump tube) to collect gastric aspirate by continuous suction while the subject was semi-recumbent. We confirmed the correct position of the tube by the water recovery test [19].

First, we collected basal gastric aspirate continuously in 15 min epochs for 30 min. Immediately afterwards, the subject took a single dose of netazepide $(1,5,25$ or $100 \mathrm{mg}$ ) or placebo by mouth with $150 \mathrm{ml}$ water. We allowed 55 min for absorption of netazepide, after which we collected gastric aspirate for $5 \mathrm{~min}$ to empty the stomach. Then, we began an intravenous infusion of pentagastrin $\left(0.6 \mu \mathrm{g} \mathrm{kg}^{-1} \mathrm{~h}^{-1}\right)$ for $2 \mathrm{~h}$, via a syringe pump. We collected gastric aspirate continuously every $15 \mathrm{~min}$ during the infusion to measure the volume, titratable acidity $\left(\mathrm{H}^{+}\right.$secretion rate) and $\mathrm{pH}$ of each sample. Subjects continued to fast until we removed the nasogastric tube at the end of the infusion. We assessed safety and tolerability of treatments by vital signs, ECG, routine safety tests of blood (haematology and biochemistry) and urine (urinalysis) and adverse events.

Repeated-dose study The study was single blind and placebo controlled. The protocol required eight healthy men or women, defined as in the single-dose study, to complete the study. Subjects were resident from Day 0 to 7 , and on Day 14. They took the following treatments by mouth: a single dose of placebo on Day 0; netazepide $(100 \mathrm{mg})$ twice daily on Days 1-6; a single dose of netazepide (100 mg) on Day 7; and a single dose of placebo on Day 14. We told all subjects that they would receive placebo on some days, but we did not tell them which days. On Days 0 , 1,7 and 14, we passed a nasogastric tube, collected and analysed gastric aspirate, dosed the subjects and infused pentagastrin as in the single-dose study. Subjects fasted on dosing days as in the single-dose study. We collected blood for plasma netazepide assay before and 1 and $3 \mathrm{~h}$ after the morning dose on Days 0, 1,7 and 14. We assessed tolerability and safety of treatments as in the single-dose study.

\section{Gastric aspirate}

In both studies, we collected gastric aspirate via the nasogastric tube into conical flasks primed with a few drops of a silicone antifoaming agent. We used a suction pump to apply continuous negative pressure of $100 \mathrm{mmHg}$ to the nasogastric tube. If necessary, we increased the negative pressure to a maximum of $600 \mathrm{mmHg}$ to clear blockage of the tube by thick mucus. We measured the volume of each collection. We also measured titratable acidity and $\mathrm{pH}$ with a $\mathrm{pH}$ meter and automatic titrator (Radiometer, Copenhagen, Denmark), which 
we calibrated with standard buffers before and after each batch of samples. We used $0.1 \mathrm{M}$ sodium hydroxide as the base, and calculated $\mathrm{H}^{+}$secretion rate in micromoles per minute.

\section{Plasma netazepide}

We collected blood and separated and stored plasma for netazepide assay by a validated HPLC-MS method [20], as described previously [5].

\section{Sample size}

Single-dose study In our previous single-dose, complete crossover study, 10 healthy subjects were enough to show significant differences in $24 \mathrm{~h}$ ambulatory gastric $\mathrm{pH}$ between netazepide $(5,25$ or $100 \mathrm{mg}$ ) and placebo [5]. Therefore, we judged that 10 subjects would be enough to detect differences in the response to pentagastrin between single doses of netazepide $(1,5,25$ or $100 \mathrm{mg})$ and placebo.

Repeated-dose study The number of subjects was determined by feasibility, rather than a power calculation. The results of the single-dose study indicated that eight subjects would be enough to show a significant effect of 13 doses of netazepide $(100 \mathrm{mg})$ vs. placebo on the response to pentagastrin.

\section{Statistics}

Single-dose study The primary outcome variable was $\mathrm{H}^{+}$ content of gastric aspirate during 60-180 min after dosing, expressed as the mean secretion rate during that period, for each subject and each treatment; that method obviated the need for an analysis of repeated measures. When $\mathrm{pH}$ was $\geq 7.0$, we set secretion rate to 0 . We analysed the results by analysis of covariance (ANCOVA) with factors treatment and subject, using subject- and session-specific basal values (0-30 min after the start of aspiration) as a covariate. We made pairwise comparisons between placebo and each dose level of netazepide with adjustment for multiple comparisons, using the Dunnett-Hsu method.

Repeated-dose study As in the single-dose study, the primary outcome variable was $\mathrm{H}^{+}$content of gastric aspirate during 60-180 min after dosing, expressed as the mean secretion rate during that period, for each subject and Day; that method obviated the need for an analysis of repeated measures. We also examined the effect of netazepide on volume and $\mathrm{pH}$ of gastric aspirate 60-180 min after dosing. We analysed the results for placebo (Day 0) and the first dose (Day 1) and last dose (Day 7) of netazepide by ANCOVA with factors treatment, subject and Day, using the subject-specific basal values on Day 0 as a covariate. Also, we did pairwise comparisons between Day 0 and each subsequent Day with adjustment for multiple comparisons, using the Dunnett-Hsu method.

\section{Results}

\section{Single-dose study}

Subjects Twelve subjects entered the study; one withdrew for personal reasons and another could not tolerate the nasogastric tube. Ten Europid subjects (six women and four men) completed the study according to the protocol. Their mean age and body mass index were 27.6 years (range $20-42$ years) and $24.6 \mathrm{~kg} \mathrm{~m}^{-2}$ (range 19.9$27.9 \mathrm{~kg} \mathrm{~m}^{-2}$ ), respectively.

Basal Before each treatment, $\mathrm{H}^{+}$secretion rate was similarly low (Table 1), and volume and $\mathrm{pH}$ differed little (Figure 1).

Placebo After placebo, pentagastrin increased the volume and $\mathrm{H}^{+}$secretion rate and reduced the $\mathrm{pH}$ of gastric aspirate (Table 1 and Figure 1). Compared with basal measurements, mean volume and $\mathrm{H}^{+}$secretion rate increased 2.4and 8-fold, respectively, and mean $\mathrm{pH}$ decreased from 2.90 to 1.29 in the epoch 60-75 min after dosing. The increase in $\mathrm{H}^{+}$concentration in gastric secretion accounted for a greater proportion of the increase in $\mathrm{H}^{+}$secretion rate than did the increase in volume.

Netazepide Single doses of netazepide $(1,5,25$ and $100 \mathrm{mg}$ ) inhibited all three measures of the response to pentagastrin in a dose-dependent manner (Table 1 and Figure 1). Netazepide $(100 \mathrm{mg})$ abolished the response. Indeed, netazepide $(100 \mathrm{mg})$ not only reversed the fall in $\mathrm{pH}$, it also increased $\mathrm{pH}$ substantially above basal levels. Compared with placebo, all doses of netazepide significantly $(P<0.02)$ reduced the mean $\mathrm{H}^{+}$secretion rate (Table 1).

\section{Table 1}

Single-dose study: mean (SD; $n=10$ ) basal and pentagastrin-induced $\mathrm{H}^{+}$ secretion rate in gastric aspirate before and after netazepide $(1,5,25$ or $100 \mathrm{mg}$ ) and placebo

\begin{tabular}{|c|c|c|}
\hline Dose & $\begin{array}{l}\text { Basal (0-30 min } \\
\text { before dosing) } \\
\text { ( } \mu \text { mol } \min ^{-1} \text { ) } \\
\text { Mean (SD) }\end{array}$ & 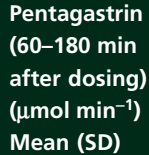 \\
\hline Placebo & $37(34)$ & 291 (103) \\
\hline Netazepide $(1 \mathrm{mg})$ & $31(30)$ & $180(141)^{\star *}$ \\
\hline Netazepide $(5 \mathrm{mg}$ ) & $22(16)$ & $140(130)^{* *}$ \\
\hline Netazepide $(25 \mathrm{mg}$ ) & $22(34)$ & $67(66)^{*}$ \\
\hline Netazepide $(100 \mathrm{mg})$ & $20(21)$ & $10(14)^{*}$ \\
\hline
\end{tabular}

Asterisks indicate significant difference $(* P<0.02$ and $* * P<0.001)$ from placebo by ANCOVA, with subject- and session-specific basal value as covariate. 
A

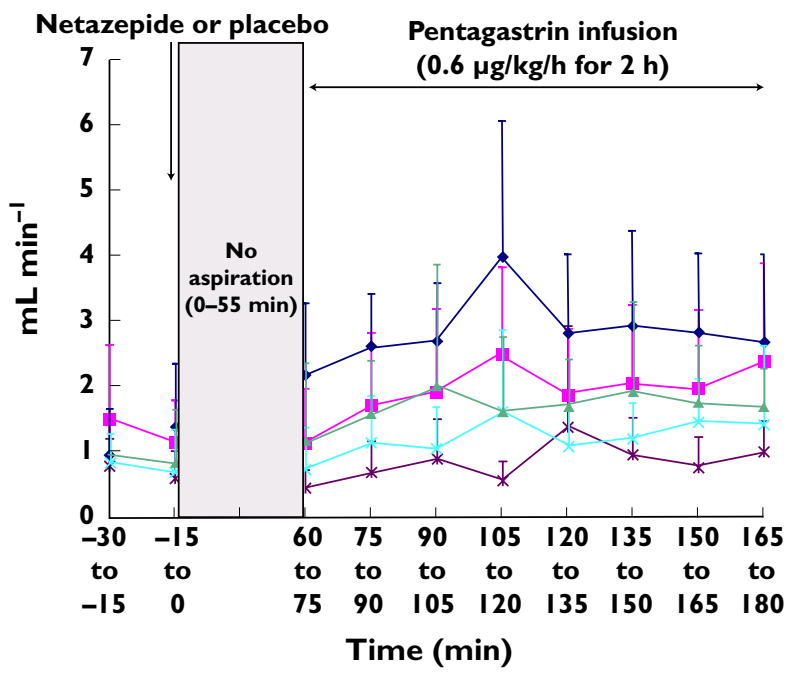

C

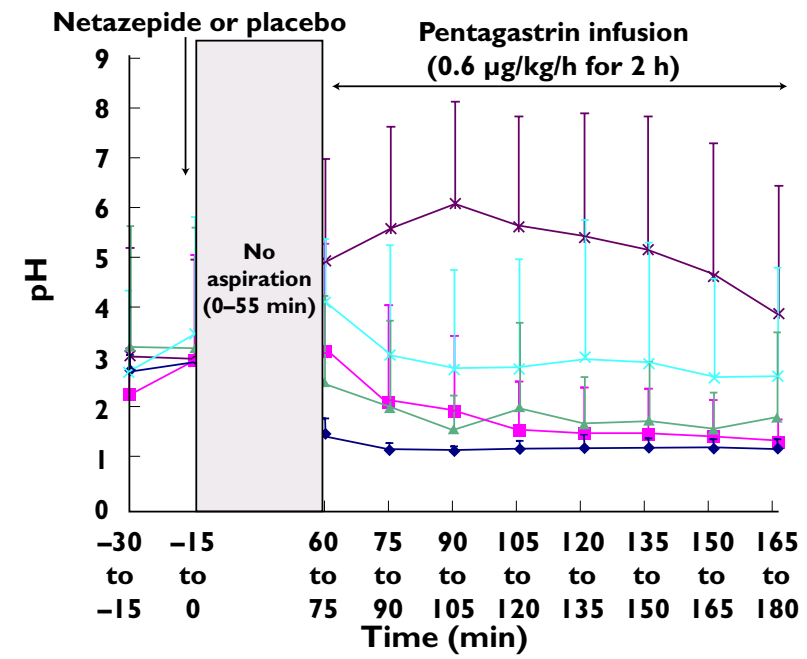

B

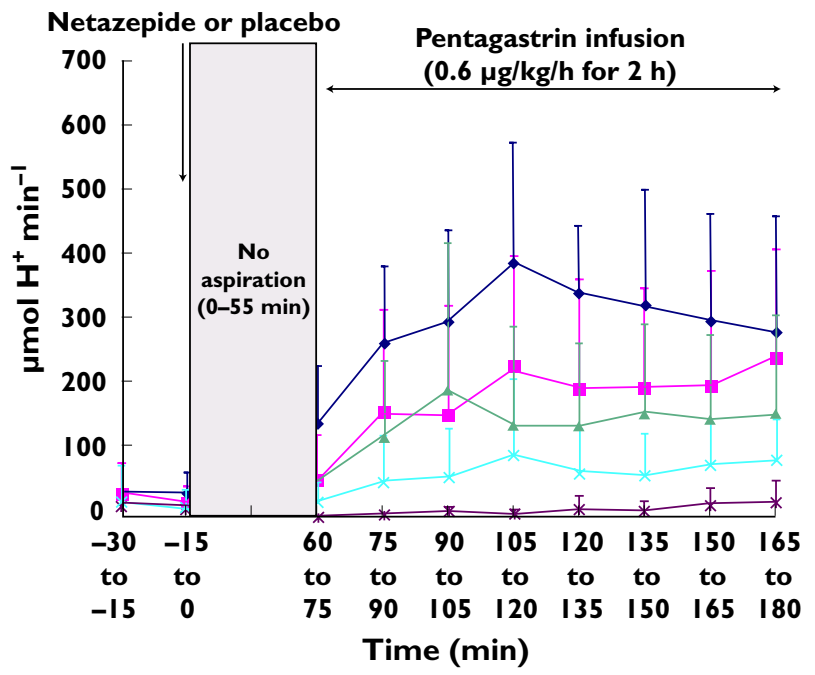

\section{Figure 1}

Single-dose study: mean ( $\mathrm{SD} ; n=10)$ basal and pentagastrin-induced volume $(\mathrm{A}), \mathrm{H}^{+}$secretion rate $(\mathrm{B})$ and $\mathrm{pH}$ of gastric aspirate $(\mathrm{C})$ before and after netazepide $\left[1(--), 5\left({ }^{-}\right), 25\left({ }^{-}\right)\right.$or $\left.100 \mathrm{mg}\left(\rightarrow^{*}\right)\right]$ and placebo $(\rightarrow-)$

Safety and tolerability Some subjects reported minor and transient adverse events, mainly sore throat, nausea, loose stools and stomach ache, after both placebo and netazepide. We attributed those adverse events to the nasogastric tube or the pentagastrin infusion. There were no clinically relevant changes in any of the safety assessments.

\section{Repeated-dose study}

Subjects Twelve subjects entered the study. None had participated in the single-dose study. Two subjects withdrew on Day 1 because of intolerance to the nasogastric tube, one withdrew for personal reasons, and we withdrew one subject because he proved to have undiagnosed, symptomless achlorhydria at entry to the study. Eight subjects (four men and four women; seven Europid and one Oriental) completed the study according to the protocol. Their mean age and body mass index were 25.8 years (range 20-44 years) and $21.9 \mathrm{~kg} \mathrm{~m}^{-2}$ (range $18.8-26.1 \mathrm{~kg} \mathrm{~m}^{-2}$ ), respectively.

Basal On Days 0, 1,7 and 14, basal $\mathrm{H}^{+}$secretion rates were similarly low, and volume and $\mathrm{pH}$ differed little (Table 2 and Figure 2).

Day 0 (placebo) After placebo, pentagastrin increased the volume and $\mathrm{H}^{+}$secretion rate and reduced the $\mathrm{pH}$ (Figure 2) of gastric aspirate. Compared with basal measurements, mean volume and $\mathrm{H}^{+}$secretion rate increased 1.7- and 4.2-fold, respectively, and mean $\mathrm{pH}$ decreased from 2.0 to 1.36 in the epoch $60-75$ min after dosing. The results were similar to those seen after placebo treatment in the single-dose study. 


\section{Table 2}

Repeated-dose study: mean (SD; $n=8$ ) basal and pentagastrin-induced volume, $\mathrm{H}^{+}$secretion rate and $\mathrm{pH}$ of gastric aspirate before and after placebo (Days 0 and 14) and before and after the first dose (Day 1) and last dose (Day 7) of 13 doses of netazepide $(100 \mathrm{mg})$ twice daily

\begin{tabular}{|cccc|}
\hline Day & $\begin{array}{l}\text { Basal (0-30 } \mathbf{m i n} \\
\text { before dosing) } \\
\text { Mean (SD) }\end{array}$ & $\begin{array}{l}\text { Pentagastrin } \\
\mathbf{( 6 0 - 1 8 0 ~} \mathbf{m i n} \\
\text { after dosing) } \\
\text { Mean (SD) }\end{array}$ \\
\hline Volume $\left(\mathrm{ml} \mathrm{min}^{-1}\right)$ & 0 & $2.4(1.7)$ & $3.8(1.3)$ \\
& 1 & $1.3(0.7)$ & $0.8(0.5)^{\star *}$ \\
& 7 & $1.0(0.5)$ & $1.3(0.5)^{\star *}$ \\
$\mathrm{H}^{+}$secretion rate & 14 & $1.6(1.2)$ & $3.2(0.8)$ \\
$\left(\mu \mathrm{mol} \mathrm{min}^{-1}\right)$ & 0 & $105(73)$ & $429(250)$ \\
& 1 & $59(43)$ & $30(53)^{* *}$ \\
& 7 & $41(38)$ & $51(40)^{* *}$ \\
$\mathrm{pH}$ & 14 & $108(142)$ & $405(119)$ \\
& 0 & $2.0(1.3)$ & $1.4(0.5)$ \\
& 1 & $1.9(0.5)$ & $4.3(2.1)^{* *}$ \\
& 7 & $2.2(1.2)$ & $1.9(0.4)$ \\
& 14 & $2.0(1.0)$ & $1.3(0.4)$ \\
\hline
\end{tabular}

Asterisks show significant difference $(* * P<0.001)$ from Day 0 by ANCOVA, with subject- and session-specific basal value as covariate.

Day 1 (first dose of netazepide) Compared with placebo on Day 0 , the first dose of netazepide $(100 \mathrm{mg})$ abolished all three measures of the response to pentagastrin (Figure 2). The reductions in mean volume and $\mathrm{H}^{+}$secretion rate and the increase in $\mathrm{pH}$ of gastric aspirate (Table 2 ) were all significant $(P<0.05)$.

Day 7 (last dose of netazepide) Compared with placebo on Day 0 , the last dose of netazepide $(100 \mathrm{mg})$ on Day 7 abolished the increases in mean volume (Figure $2 \mathrm{~A}$ ) and $\mathrm{H}^{+}$secretion rate (Figure $2 \mathrm{~B}$ ) of aspirate induced by pentagastrin, as did the first dose on Day 1 , but failed to achieve the increase in $\mathrm{pH}$ that netazepide caused on Day 1 (Table 2 and Figure 2C). The reductions in volume and $\mathrm{H}^{+}$secretion rate (Table 2$)$ were significant $(P<0.001)$, whereas the effect on $\mathrm{pH}$ did not differ significantly from placebo.

Day 14 (placebo) On Day 14, 7 days after the last dose of netazepide, the three measures of the response to pentagastrin after placebo were similar to those after placebo on Day 0 (Table 2 and Figure 2).

Plasma netazepide Mean (range) plasma netazepide concentrations (in nanograms per millilitre) at 60 and $180 \mathrm{~min}$ after dosing on Day 1 were 118.2 (1.4-302.9) and 18.5 (2.7$34.2)$, respectively, and on Day 7 were 48.2 (22.3-94.6) and $25.0(9.2-78.3)$, respectively.

Safety and tolerability Some subjects reported adverse events after placebo and netazepide, which were similar to those reported by subjects in the single-dose study. There were no clinically relevant changes in any of the safety assessments.

\section{Discussion}

In both studies, which were done in different groups of subjects, basal volume, $\mathrm{H}^{+}$secretion rate and $\mathrm{pH}$ of gastric aspirate were low on all study days, as would be expected after an overnight fast. Also in both studies, pentagastrin increased the volume and $\mathrm{H}^{+}$secretion rate of gastric aspirate and reduced the $\mathrm{pH}$ after every dose of placebo. The increase in $\mathrm{H}^{+}$concentration in gastric secretion accounted for a greater proportion of the increase in $\mathrm{H}^{+}$ secretion rate than did the increase in volume. Pentagastrin $\left(0.6 \mu \mathrm{g} \mathrm{kg}^{-1} \mathrm{~h}^{-1}\right)$, which is a submaximal dose, was well tolerated.

In both studies, netazepide was well tolerated, and a single dose inhibited all three measures of the response to pentagastrin. In the single-dose study, netazepide $(1,5,25$ and $100 \mathrm{mg}$ ) caused dose-dependent inhibition of the pentagastrin-stimulated increases in the volume and $\mathrm{H}^{+}$ secretion rate and the reduction in $\mathrm{pH}$ of gastric aspirate. Netazepide $(100 \mathrm{mg})$ abolished all three measures of the response to pentagastrin. In the repeated-dose study, the effects of the first of the 13 doses of netazepide $(100 \mathrm{mg})$ were very similar to those of netazepide $(100 \mathrm{mg})$ in the single-dose study. Also, the effects of the last of the 13 doses of netazepide $(100 \mathrm{mg})$ on pentagastrin-stimulated increases in volume and $\mathrm{H}^{+}$secretion rate were similar to those of the first dose; but, compared with the first dose, the last dose had much less effect on the $\mathrm{pH}$ response to pentagastrin, as in our previous studies, in which we measured $\mathrm{pH}$ by the $24 \mathrm{~h}$ ambulatory method [6].

Dose-dependent inhibition of the response to pentagastrin by single doses of netazepide is consistent with antagonism of gastrin/ $/ \mathrm{CK}_{2}$ receptors. Suppression of pentagastrin-induced increases in volume and $\mathrm{H}^{+}$secretion rate of gastric aspirate by repeated doses of netazepide is consistent with persistent antagonism. Those findings support our conclusion that the increase in plasma gastrin after repeated doses of netazepide in our previous studies [6] reflects suppression of gastric acid secretion via antagonism of gastrin receptors and upregulation of the gastrin gene [7-16]. All our findings thus far are in accord with those of nonclinical studies, which have shown netazepide to be an orally active, highly selective and competitive antagonist of gastrin/ $\mathrm{CCK}_{2}$ receptors [1-3] whose action persists after chronic dosing $[8,9]$.

We allowed $60 \mathrm{~min}$ after netazepide dosing before starting infusion of pentagastrin, because that was about the time of maximal plasma concentration in our previous studies $[5,6]$. Netazepide concentrations at 60 and $90 \mathrm{~min}$ after dosing on Days 1 and 7 in the repeated-dose study were variable, and were only $10-15 \%$ of those measured at 
A

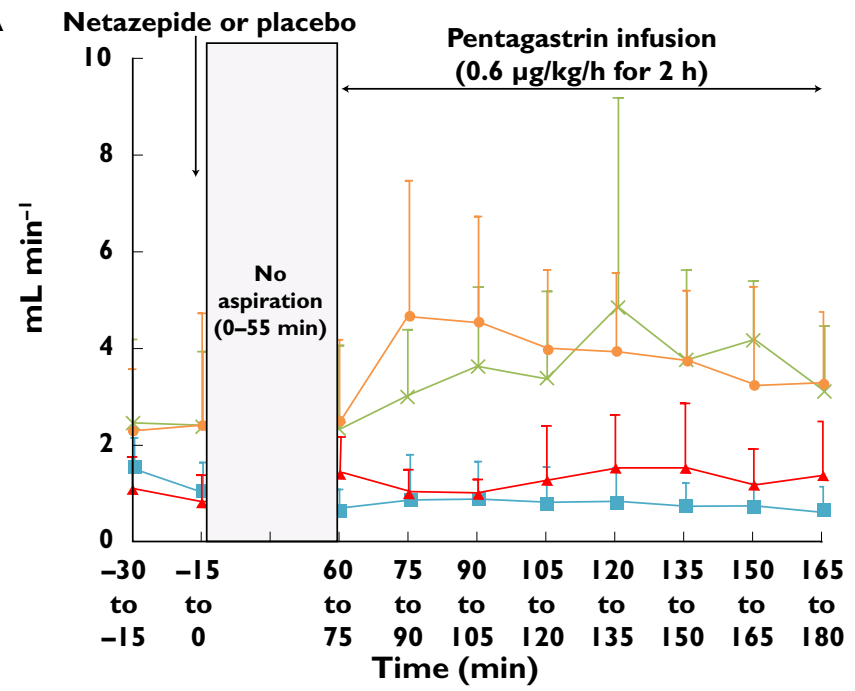

B Netazepide or placebo

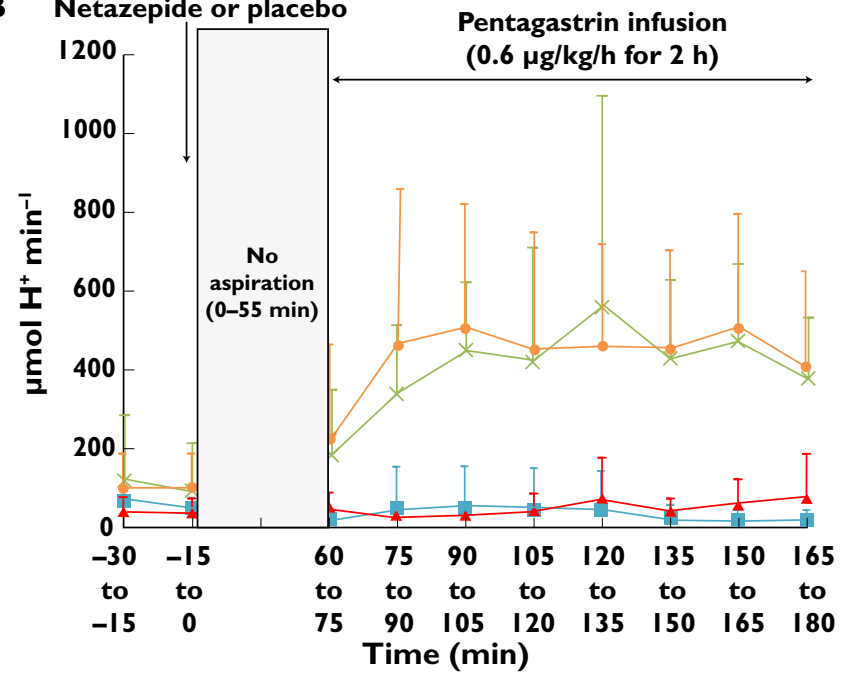

C Netazepide or placebo

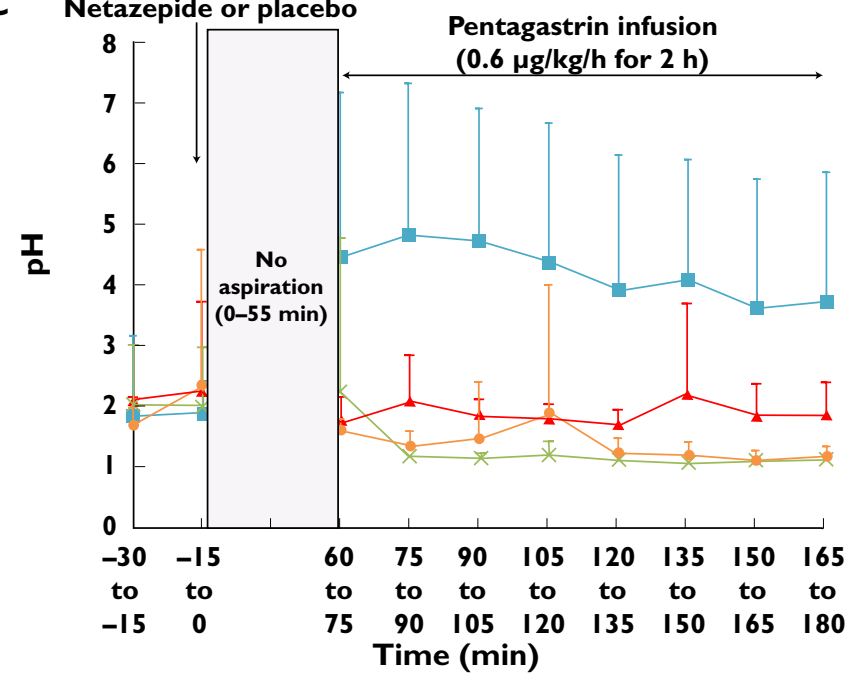

Pentagastrin infusion

\section{Figure 2}

Repeated-dose study: mean (SD; $n=8)$ basal and pentagastrin-induced volume $(\mathrm{A}), \mathrm{H}^{+}$secretion rate $(\mathrm{B})$ and pH of gastric aspirate $(\mathrm{C})$ after placebo on Day $0(-)$ and Day $14\left({ }^{-}\right)$, and after the first dose on Day $1(-)$ and last dose on Day $7(-)$ of 13 doses of 100 mg netazepide twice daily

similar times after dosing in our previous studies $[5,6]$. The reason is that for those studies the sponsor supplied what we now know to be a much more bioavailable formulation. Clearly, netazepide is an effective gastrin/ $\mathrm{CCK}_{2}$ receptor antagonist in man, even at low plasma concentrations.

After only 7 days of netazepide (100 mg) twice daily, nearly complete tolerance had developed. That phenomenon resembles the development of tolerance to the effect of netazepide on $24 \mathrm{~h}$ ambulatory gastric $\mathrm{pH}$ after repeated doses in our previous studies [6]. What might be the mechanism of that tolerance?

Tolerance might reflect a change in a constituent of gastric juice which takes longer to occur than does the immediate effect on acid production and which reduces the buffering capacity of gastric juice. Gastric juice contains many substances apart from hydrochloric acid, including pepsin, mucus, peptides, amino acids and electrolytes, such as bicarbonate $\left(\mathrm{HCO}_{3}{ }^{-}\right)$and phosphate. Also, it usually contains saliva and sometimes bile. In man, the buffers of $\mathrm{H}^{+}$in gastric juice, which prevent large changes in gastric $\mathrm{pH}$, are mainly $\mathrm{HCO}_{3}{ }^{-}[21]$, nonpepsin protein [22-24] and phosphate [25]. Pepsin degradation products of nonpepsin protein may also add to the buffering capacity of gastric juice [26]. Nonprotein buffers, especially $\mathrm{HCO}_{3}{ }^{-}$, probably play a more important role than do the other buffers [24]. Mucin, the protein of mucus, has little, if any, buffering activity [22].

Various studies have been carried out to assess the mechanisms that control gastric $\mathrm{HCO}_{3}^{-}$secretion in humans. Bicarbonate secretion was increased by cholinergic stimulation and reduced by prostaglandin $\mathrm{E}_{2}[27]$ but was unaffected by pentagastrin [27, 28]. Sham feeding 
stimulated gastric $\mathrm{HCO}_{3}{ }^{-}$secretion, confirming its central nervous system control via the vagus [29-31]. Bicarbonate is difficult to measure in the presence of acid, and must first be unmasked by suppressing acid production with a histamine $\mathrm{H}_{2}$-receptor antagonist $\left(\mathrm{H}_{2} \mathrm{RA}\right)$ or a proton pump inhibitor (PPI) [32]. Using that method, the rate of secretion of $\mathrm{HCO}_{3}{ }^{-}$by the human stomach in vivo was equivalent to $10-20 \%$ of basal acid secretion [32]. Repeated doses of neither an $\mathrm{H}_{2} \mathrm{RA}$ nor a PPI affected $\mathrm{HCO}_{3}{ }^{-}$secretion [33]. However, the different methods by which gastric $\mathrm{HCO}_{3}{ }^{-}$ secretion has been measured in humans have produced discordant results [34]. Nevertheless, the available evidence suggests that gastrin is not directly involved in control of gastric $\mathrm{HCO}_{3}{ }^{-}$secretion.

Gastrin, a hormone secreted by Gcells in the gastric antrum [17], stimulates gastrin receptors on enterochromaffin-like cells in the gastric mucosa to secrete histamine, which in turn stimulates adjacent gastric parietal cells to secrete acid into the lumen of the stomach. Secretion of gastric acid is mediated by the action of $\mathrm{H}^{+}, \mathrm{K}^{+}$ATPase (the proton pump) in response to stimulation of histamine $\mathrm{H}_{2}$ receptors or muscarinic $\mathrm{M}_{3}$ receptors. There is evidence that parietal cells also express gastrin receptors [35], although their role in acid secretion is uncertain [36]. Gastrin also acts as a growth factor on normal gastric oxyntic mucosa, stimulating enterochromaffin-like and parietal cell growth $[17,37,38]$. Recent studies using knockout mice that either lack the gastrin gene or overexpress it, as well as genomic methods, have revealed that the physiological role of gastrin is far more than regulation of acid secretion [39-41]. Gastrin is pivotal in organizing and maintaining the structure of gastric epithelium. It upregulates various genes, such as histidine decarboxylase, vesicular monoamine transporter type 2, chromogranin A and protein Reg 1A [37], and stimulates paracrine cascades [38], including cytokines, growth factors, such as trefoil factor [42, 43], and prostanoids. Gastric acid secretion is regulated by endocrine, paracrine and neurocrine mechanisms via at least three signalling pathways: gastrinhistamine (stimulation), $\mathrm{CCK}_{1}$-somatostatin (inhibition) and the neural network (both stimulation and inhibition). Studies in gene-knockout mice have shown that there is complex interplay among those pathways $[36,44]$. Different pathways are suppressed or dominate, depending on the circumstances. It is possible, therefore, that antagonism of gastrin receptors by repeated doses of netazepide led to a switch in control of the buffering capacity of gastric juice in our study.

What might be the impact of the tolerance to gastric $\mathrm{pH}$ on the potential therapeutic uses of netazepide? Gastric $\mathrm{pH}$ is easy to measure continuously with a nasogastric electrode, and has been widely used as a surrogate clinical end-point in trials of the acid suppressants $\mathrm{H}_{2} \mathrm{RA}$ and PPI [45]. A substantial increase in the duration for which $\mathrm{pH}$ is $\geq 4$ is regarded as essential to heal peptic ulcers or erosive oesophagitis. Given that $\mathrm{pH}$ is a logarith- mic scale, the gastric $\mathrm{pH}$ may change little despite a large change in $\mathrm{H}^{+}$secretion $[36,46]$. Furthermore, measurement of gastric $\mathrm{pH}$ alone ignores changes in volume. Therefore, the amount of $\mathrm{H}^{+}$secreted per unit time is a more sensitive and reliable test of acid suppression than is $\mathrm{pH}$. Repeated doses of netazepide cause persistent blockade of gastrin receptors and could prove a useful treatment for patients with acid-related conditions, such as gastro-oesophageal reflux disease, despite tolerance to the effect on $\mathrm{pH}$. Likewise, netazepide should inhibit the trophic effects of gastrin on parietal and/or enterochromaffin-like cells in the gastric mucosa $[17,37,38]$, for example in patients with hypergastrinaemia caused by autoimmune chronic atrophic gastritis [47], Zollinger-Ellison syndrome [47] and prolonged PPI [48-51] or $\mathrm{H}_{2} \mathrm{RA}$ treatment [52]. Indeed, in pilot studies in patients with chronic atrophic gastritis and multiple gastric carcinoids secondary to hypergastrinaemia, netazepide reduced the number and size of the tumours and normalized plasma chromogranin A, which increased to pretreatment levels after netazepide was stopped $[53,54]$. Chromogranin A is a validated biomarker of increased activity of enterochromaffin-like cells, from which the gastric carcinoids originate.

Many gastrin receptor antagonists have been described $[55,56]$, but most have had problems with selectivity, potency or bioavailability. Several have been tested in man [57-61], but none has been developed as a medicine. Whether tolerance to the effect on gastric $\mathrm{pH}$ is specific to netazepide or a class effect must await studies of other gastrin receptor antagonists.

The design of the single-dose study was ideal; randomized, double blind, placebo controlled, complete crossover and a range of doses. The design of the repeated-dose study - single blind, fixed dose and no randomization was a compromise, but the methods are robust and the results have face validity.

\section{Conclusions}

In healthy subjects, netazepide is an orally active, potent, competitive antagonist of gastrin/ $\mathrm{CCK}_{2}$ receptors in the stomach. Antagonism is dose dependent, and persists during repeated dosing, despite the reduced effect on $\mathrm{pH}$. Further studies are required to find the mechanism of that reduced effect. Netazepide is a tool to study the physiology and pharmacology of gastrin, and merits studies in patients to assess its potential to treat gastric acid-related conditions and the trophic effects of hypergastrinaemia.

\section{Competing Interests}

All authors have completed the Unified Competing Interest form at http://www.icmje.org/coi_disclosure.pdf (available on request from the corresponding author). Netazepide (YF476) came from research by Ferring, Chilworth, England. The James Black Foundation licensed 
netazepide from Ferring temporarily in 2001 to sponsor these studies. In 2006, Ferring licensed netazepide to Trio Medicines Ltd, a subsidiary of Hammersmith Medicines Research (HMR), a contract research organization. M.B. and S.W. are directors of HMR and Trio Medicines Ltd, and M.B. owns both companies. Sadly, Sir James Black, who helped design the studies and contributed to the interpretation of the results, died in March 2010.

\section{REFERENCES}

1 Semple G, Ryder H, Rooker D, Batt A, Kendrick D, Szelke M, Ohta M, Satoh M, Nishida A, Akuzawa S, Miyata K. (3R)-N-(1-(tert-butylcarbonylmethyl)-2,3-dihydro-2-oxo-5(2-pyridyl)-1H-1,4-benzodiazepin-3-yl)-N'-(3-(methylamino) phenyl)urea (YF476): a potent and orally active gastrin/CCK-B antagonist. J Med Chem 1997; 31: 331-41.

2 Takinami Y, Yuki H, Nishida A, Akuzawa S, Uchida A, Takemoto Y, Ohta M, Satoh M, Semple G, Miyata K. YF476 is a new potent and selective gastrin/cholecystokinin-B receptor antagonist in vitro and in vivo. Aliment Pharmacol Ther 1997; 11: 113-20.

3 Takemoto Y, Yuki H, Nishida A, Ito H, Kobayashi-Uchida A, Takinami Y, Akuzawa S, Ohta M, Satoh M, Semple G, Miyata K. Effects of YF476, a potent and selective gastrin/CCK-B receptor antagonist, on gastric acid secretion in beagle dogs with gastric fistula. Arzneim Forsch 1998; 48: 403-7.

4 Alexander SP, Mathie A, Peters JA. Guide to receptors and channels (GRAC). Br J Pharmacol 2011; 164 (Suppl. 1): S1-324.

5 Boyce M, David O, Darwin K, Mitchell T, Johnston A, Warrington S. Single oral doses of netazepide (YF476), a gastrin receptor antagonist, cause dose-dependent, sustained increases in 24-h gastric $\mathrm{pH}$ compared with placebo and ranitidine in healthy subjects. Aliment Pharmacol Ther 2012; 36: 181-9.

6 Boyce M, Warrington S. Effect of repeated doses of netazepide, a gastrin receptor antagonist, omeprazole and placebo on 24-h gastric acidity and gastrin in healthy subjects. Br J Clin Pharmacol 2013; 76: 680-8.

7 Ding X-Q, Lindström E, Håkanson R. Evaluation of three novel cholecystokinin-B/gastrin receptor antagonists: a study of their effects on rat stomach enterochromaffin-like cell activity. Pharmacol Toxicol 1997; 81: 232-7.

8 Chen D, Håkanson R, Rehfeld J, Zhao C-M. CCK2 receptors are necessary for the differentiation and proliferation of ECL cells in mouse and rat stomach. Inflammopharmacology 2000; 10: 351-64.

9 Kitano M, Norlén P, Ding X-Q, Nakamura S, Håkanson R. Long-lasting CCK2 receptor blockade after a single subcutaneous injection of YF476 or YM022. Br J Pharmacol 2000; 130: 699-705.

10 Konagaya $T$, Bernsand $M$, Norlén $P$, Håkanson R. Mobilization of rat stomach ECL-cell histamine in response to short- or long-term treatment with omeprazole and/or YF476 studied by gastric submucosal microdialysis in conscious rats. $\mathrm{Br} \mathrm{J}$ Pharmacol 2001; 133: 37-42.

11 Björkqvist M, Dornonville de la Cour C, Zhao CM, Gagnemo-Persson R, Håkanson R, Norlén P. Role of gastrin in the development of gastric mucosa, ECL cells and A-like cells in newborn and young rats. Regul Pept 2002; 108: 73-82.

12 Martinsen T, Kawase S, Håkanson R, Torp S, Fossmark R, Qvigstad G, Sandvik A, Waldum H. Spontaneous ECL cell carcinomas in cotton rats: natural course and prevention by a gastrin receptor antagonist. Carcinogenesis 2003; 24: 1887-96.

13 Takaishi S, Cui G, Frederick D, Carlson J, Houghton J, Varro A, Dockray G, Ge Z, Whary M, Rogers A, Fox J, Wang T. Synergistic inhibitory effects of gastrin and histamine receptor antagonists on Helicobacter-induced gastric cancer. Gastroenterology 2005; 128: 1965-83.

14 Cui G, Takaishi S, Ai W, Betz KS, Florholmen J, Koh T, Houghton J, Pritchard M, Wang T. Gastrin-induced apoptosis contributes to carcinogenesis in the stomach. Lab Invest 2006; 86: 1037-51.

15 Kidd M, Siddique Z, Drozdov I, Gustafsson B, Camp R, Black J, Boyce M, Modlin I. The CCK(2) receptor antagonist, YF476, inhibits Mastomys ECL-cell hyperplasia and gastric carcinoid tumor development. Regul Pept 2010; 162: 52-60.

16 Takaishi S, Shibata W, Tomita H, Jin G, Yang X, Ericksen R, Dubeykovskaya Z, Asfaha S, Quante M, Betz KS, Shulkes A, Wang $T$. In vivo analysis of mouse gastrin gene regulation in enhanced GFP-BAC transgenic mice. Am J Physiol Gastrointest Liver Physiol 2011; 300: G334-344.

17 Dockray G, Varro A, Dimaline R, Wang T. The gastrins: their production and biological activities. Annu Rev Physiol 2001; 63: 119-39.

18 Boyce M, Warrington S, Nentwich H, Norris V, Hull R, Black J. Effect of repeated doses of YF476, a gastrin antagonist, on pentagastrin-induced changes in volume, $\mathrm{H}^{+}$content and $\mathrm{pH}$ of gastric aspirate in healthy subjects [abstract]. $\mathrm{Br} \mathrm{J}$ Clin Pharmacol 2004; 57: 684P.

19 Hassan M, Hosbley J. Positioning of subject and nasogastric tube during gastric secretion study. Br Med J 1970; 1: 458-60.

20 Redrup M, Leaf F, Miyashita A, Watanabe T, Higuchi S, Chasseaud L, Cheng K. Validation of a liquid chromatographic-tandem mass spectrometric method for the measurement of (R)-1-[2,3- dihydro-2-oxo-1pivaloylmethyl-5-(2-pyridyl)-1H-1,4-benzodiazepin-3-yl]-3(3methylaminophenyl)urea (YF476) in human plasma. J Chromatogr 2002; 772: 317-25.

21 Allen A, Flemström G. Gastroduodenal mucus bicarbonate barrier: protection against acid and pepsin. Am J Physiol Cell Physiol 2005; 288: C1-C19.

22 Mitchell T. The buffer substances of the gastric juice, and their relation to gastric mucus. J Physiol 1931; 73:427-43.

23 Makhlouf G, Blum A, Moore E. Undissociated acidity of human gastric juice. Measurement and relationship to protein buffers. Gastroenterology 1970; 58: 345-51. 
24 Popiela T, Szafran Z, Szafran H, Komorowska M. Relationship between undissociated acidity of gastric juice and gastric protein in response to graded doses of pentagastrin in duodenal ulcer patients. Gut 1977; 18: 208-13.

25 Burhol PG, Myren J, Foss OP. Electrolytes in gastric juice of man. (I). A statistical analysis of calcium and inorganic phosphorus before and after subcutaneous injection of large doses of histamine. Scand J Clin Lab Invest 1966; 18: 325-30.

26 Fordtran J, Walsh J. Gastric acid secretion rate and buffer content of the stomach after eating. J Clin Invest 1973; 52: 645-57.

27 Feldman M. Gastric bicarbonate secretion in humans. Effect of pentagastrin, bethanechol and prostaglandin E2. J Clin Invest 1983; 72: 293-303.

28 Hamlet A, Dalenback J, Olbe L, Fandriks L. Does antral distension inhibit gastric acid secretion or stimulate bicarbonate secretion in 'healthy' subjects? Scand J Gastroenterol 1993; 28: 999-1004.

29 Forssell H, Stenquist B, Olbe L. Vagal stimulation of human gastric bicarbonate secretion. Gastroenterology 1985; 89 : 581-6.

30 Feldman M. Gastric $\mathrm{H}^{+}$and $\mathrm{HCO}^{-}$secretion in response to sham feeding in humans. Gastrointest Liver Physiol 1985; 11: G188-G191.

31 Konturek S, Kwiecień N, Obtułowicz W, Thor P, Konturek JW, Popiela T, Oleksy J. Vagal cholinergic control of gastric alkaline secretion in normal subjects and duodenal ulcer patients. Gut 1987; 28: 739-44.

32 Rees W, Botham D, Turnberg L. A demonstration of bicarbonate secretion production by the normal stomach in vivo. Dig Dis Sci 1982; 27: 961-6.

33 Lonnerholm G, Knutson L, Wistrand P, Flemström G. Carbonic anhydrase in the normal rat stomach and duodenum and after treatment with omeprazole and ranitidine. Acta Physiol Scand 1989; 36: 253-62.

34 Odes H, Hogan D, Steinbach J, Ballesteros M, Koss M, Isenberg J. Measurement of gastric bicarbonate in the human stomach: different methods produce discordant results. Scand J. Gastroenterology 1992; 27: 829-36.

35 Schmitz F, Göke MN, Otte J, Schrader H, Reimann B, Kruse M, Siegel E, Peters J, Herzig K, Fölsch U, Schmidt W. Cellular expression of CCK-A and CCK-B/gastrin receptors in human gastric mucosa. Regul Pept 2001; 102: 101-10.

36 Chen D, Zhao C-M. Complexity of gastric acid secretion by targeted gene disruption in mice. Curr Pharm Des 2010; 16 : 1235-40.

37 Dimaline R, Varro A. Attack and defence in the gastric epithelium - a delicate balance. Exp Physiol 2007; 92: 591-601.

38 Almeida-Vega S, Catlow K, Kenny S, Dimaline R, Varro A. Gastrin activates paracrine networks leading to induction of PAI-2 via MAZ and ASC-1. Am J Physiol Gastrointest Liver Physiol 2009; 296: G414-G423.
39 Chen D, Friis-Hansen L, Håkanson R, Zhao C-M. Genetic dissection of the signalling pathways that control gastric acid secretion. Inflammopharmacology 2005; 13: 201-7.

40 Zhao CM, Martinez V, Piqueras L, Wang L, Taché Y, Chen D. Control of gastric acid secretion in somatostatin receptor 2 deficient mice: shift from endocrine/paracrine to neurocrine pathways. Endocrinology 2008; 149: 498-505.

41 Kanai S, Hosoya H, Akimoto S, Ohta M, Matsui T, Takiguchi S, Funakoshi A, Miyasaka K. Gastric acid secretion in cholecystokinin-1 receptor, -2 receptor, and -1, -2 receptor gene knockout mice. J Physiol Sci 2009; 59: 23-9.

42 Khan ZE, Wang TC, Cui G, Chi AL, Dimaline R. Transcriptional regulation of the human trefoil factor, TFF1, by gastrin. Gastroenterology 2003; 125: 510-21.

43 Tu S, Chi AL, Lim S, Cui G, Dubeykovskaya Z, Ai W, Fleming JV Takaishi S, Wang T. Gastrin regulates the TFF2 promoter through gastrin-responsive cis-acting elements and multiple signaling pathways. Am J Physiol Gastrointest Liver Physiol 2007; 292: G1726-1737.

44 Chen D, Zhao C-M. Genetically engineered mice: a new paradigm to study gastric physiology. Curr Opin Gastroenterol 2007; 23: 602-6.

45 van Herwaarden M, Samson M, Smout A. 24-h recording of intragastric $\mathrm{pH}$ : technical aspects and clinical relevance. Scand J Gastroenterol 1999; 230: 9-16.

46 Johnston D, Wormsley K. Problems with the interpretation of pH measurements. Clin Investig 1993; 72: 12-7.

47 Burkitt M, Pritchard D. Pathogenesis and management of gastric carcinoid tumours. Aliment Pharmacol Ther 2006; 24: 1305-20.

48 Ligumsky M, Lysy J, Siguencia G, Friedlander Y. Effect of long-term, continuous versus alternate-day omeprazole therapy on serum gastrin in patients treated for reflux oesophagitis. J Clin Gastroenterol 2001; 33: 3-7.

49 Reimer C, Søndergaard B, Hilsted L, Bytzer P. Proton-pump inhibitor therapy induces acid-related symptoms in healthy volunteers after withdrawal of therapy. Gastroenterology 2009; 137: 80-7.

50 Niklasson A, Lindström L, Simrén M, Lindberg G, Björnsson E. Dyspeptic symptom development after discontinuation of a proton pump inhibitor: a double-blind placebo-controlled trial. Am J Gastroenterol 2010; 105: 1531-7.

51 Jalving M, Koornstra J, Wesseling J, Boezen H, De Jong S, Kleibeuker J. Increased risk of fundic gland polyps during long-term proton pump inhibitor therapy. Aliment Pharmacol Ther 2006; 24: 1341-8.

52 Smith J, Davey C, Nwekol C, Pounder R. Tolerance during 8 days of high-dose $\mathrm{H}_{2}$-blockade: placebo-controlled studies of 24-hour acidity and gastrin. Aliment Pharmacol Ther 1990; 4 (Suppl. 1): 47-63.

53 Fossmark R, Sørdal O, Jianu C, Qvigstad G, Nordrum I, Boyce $\mathrm{M}$, Waldum $\mathrm{H}$. Treatment of gastric carcinoids type 1 with the gastrin receptor antagonist netazepide (YF476) results in regression of tumours and normalisation of serum chromogranin A. Aliment Pharmacol Ther 2012; 36: 1067-75. 
54 Moore A, Ball L, Boyce M, Varro A, Pritchard DM. The novel gastrin/CCK2 receptor antagonist YF476 induces clinical responses in patients with type I gastric neuroendocrine tumours. Gut 2012; 61 (Suppl. 2): A42-A43.

55 McDonald I. CCK-2 receptor antagonists. Exp Opin Ther Patents 2001; 11: 445-62.

56 Black JW, Kalindjian B. Gastrin agonists and antagonists. Pharmacol Toxicol 2002; 91:275-81.

57 Murphy M, Sytnik B, Kovacs T, Mertz H, Ewanik D, Shingo S, Lin J, Gertz B, Walsh J. The gastrin-receptor antagonist L-365,260 inhibits stimulated acid secretion in humans. Clin Pharmacol Ther 1993; 54: 533-9.

58 Beltinger J, Hildebrand P, Drewe J, Christ A, Hlobil K, Ritz M, D'Amato M, Rovati L, Beglinger C. Effect of spiroglumide, a gastrin-receptor antagonist, on acid secretion in humans. Eur J Clin Invest 1999; 29: 153-9.
59 Kramer M, Cutler N, Ballenger J, Patterson W, Mendels J, Chenault A, Shrivastava R, Matzura-Wolfe D, Lines C, Reines S. A placebo-controlled trial of L-365,260, a CCK-B antagonist, in panic disorder. Biol Psychiatry 1995; 37: 462-6.

60 Adams J, Pyke R, Costa J, Cutler N, Schweizer E, Wilcox C, Wisselink P, Greiner M, Pierce M, Pande A. A double-blind placebo-controlled study of a CCK-B receptor antagonist, $\mathrm{Cl}-988$, in patients with generalised anxiety disorder. J Clin Psychopharmacol 1995; 15: 428-34.

61 Black JW. Reflections on some pilot trials of gastrin receptor blockade in pancreatic cancer. Eur J Cancer 2009; 45: 360-4. 